\title{
Global Portfolio Diversification and Equity Market: Evidence from Trading Partners of Pakistan
}

\author{
Muhammad Husnain $^{1}$, , Um-e-Habiba ${ }^{2}$, Shahnaz Akhtar Arifullah ${ }^{3}$, Izhar Muhammad ${ }^{4}$ \\ ${ }^{1}$ Universidad de Extremadura, Spain. \\ ${ }^{2}$ School of Finance $\mathcal{E}$ Economics, Jiangsu University, China. \\ ${ }^{3}$ Institute of Development Studies, The University of Agriculture, Peshawar, Pakistan. \\ ${ }^{4}$ Capital University of Science and Technology, Islamabad, Pakistan.
}

\begin{abstract}
The influential work of Markowitz $(1952,1959)$ provides foundation to modern investment philosophy. Investors can reap the potential benefit of portfolio diversification only if the involved asset classes in investment basket are not perfectly correlated. Objective of this study is to empirically investigate the cointegration among equity market of Pakistan and its major trading partners (China, France, Germany, Hong Kong, Japan, Korea, Malaysia, UK and USA). Sample period of study starts from 2004 to 2015, on weekly basis. Bivariate cointegration (Johansen, 1991, 1995) analysis reveals that equity market of Pakistan has no long term relationship with any of the equity markets of its major trading partners. Therefore, we recommend to potential investors, portfolio managers, and policy makers that prospective benefit of portfolio diversification can be achieved by investing in the equity markets of major trading partners of Pakistan. Further, they should be vigilant regarding the co-movement among equity markets during portfolio management decisions.
\end{abstract}

\section{Introduction}

Globalizations of economies, deregulation of economic activities and rapid advances in communication technologies have enabled the stock markets to effectively mobilize savings across international borders. This phenomenon is contributing to well being of all nations in the shape of increased savings and investments, competitive prices, developed financial as well as product markets. Advanced capital markets and liberalization of stock markets have increased the investors interest in international diversification (Cotter and Stevenson, 2006; Kallberg et al., 2002; Liow et al., 2009). Diversification means reducing investment risk and increasing the probability of returns by putting investment in different security assets, subject to the condition that the values of the securities do not dance in unison (having no perfect or near perfect correlation).

Theory of diversification suggests that there are two major causes of risk in investment. Firstly, the security in which investor invests loses its value abruptly due to some unexpected or unforeseen events. The second major cause of downward movement of the value of a security asset is due to factors like overinvestment in it. If the value of a firm starts upward movement due to some favourable news, investors start buying it. The buying momentum may continue till the asset

*Corresponding author.

Email: husnain207@hotmail.com is overpriced. When investors realise that the security has been overpriced, they start selling it. As a result of selling, value of the asset starts declining, bringing the value of the security down below its real (intrinsic) value. If funds are invested in more than one assets, the chances or (risks) of losing all investment due to some unforeseen incident(s) diminishes because it is less likely that the values of all invested assets would fall simultaneously (Ghosh and John, 1999; Gupta and Guidi, 2012; Hoque et al., 2007; Mukherjee and Bose, 2008; Siklos and Ng, 2001; Wong et al., 2004). In case there is a synchronised up and downward movement of values among securities, investing in them would be like investment in a single security and thus chances of losses would be maximum. Therefore, investors and fund managers should initially examine the past history of the changing values of asset and then invest in the security that is having independent movement trend in its values.

Looking from a different perspective, linking of international markets can pose another challenge to the investors as well as international financial integration. Recently, some financial markets have been showing synchronised reactions to some common events (e.g; stock markets response to credit market failure in United States in 2008). This trend has forced the financial analysts to reassess the heterogeneity in the 
movement of stock prices in different countries. If the integration of equity markets of different countries has reached to a level that one common shock can affect it equally, then diversified investment in it may not give the expected positive results (Chuluun and Graham, 2016; Cohen et al., 2008; Fu and GuptaMukherjee, 2014). The purpose of this study is to empirically investigate co-movement in the stock markets of the countries with which Pakistan has major trade relations. Hence, it is an attempt to analyze the long term as well as short term relationship between Pakistani equity market and equity markets of its major trading partners.

If there is long term relationship between Pakistani equity market and equity markets of its major trading partners then it can be safely concluded that there is no opportunity in term of portfolio diversification for Pakistani investor in the equity markets of its major trading partners. Hence this study will contribute in the existing literature by giving proper guidelines to investors, financial institutions and policy makers that they should be vigilant regarding the co-movement between equity markets before taking any prosperous investment decision. This study is important and lucrative for international investors as it may prove helpful to guide their investments decisions. They should be vigilant regarding the long term relationship between equity market of Pakistan and its major trading partners before attracting any flourish decision.

\section{Literature Review}

The followers of the modern portfolio theory believed that investors and fund managers can put their total assets into different baskets and can invest into different across boarder markets until and unless the return from the international markets is perfectly correlated with the return of domestic market. The prior studies examined that this portfolio diversication include Lessard (1973), Levy and Sarnat (1970) and Solnik (1974). But these are the earliest studies that proved the theory of diversification, i.e. it reduces the risk of basket. Hence if the stock markets of different countries are highly interrelated then this interdependence can wipe out the benefit of diversification for investors. Moreover, if markets are integrated then any financial crises in one economy may proof a source of disturbance for other interlinked economies (Cotter and Stevenson, 2006; Liow et al., 2009; Liow and Yang, 2005). A number of studies explored the interdependences between the equity markets of different countries by using various econometrics models such as Kasa (1992), Liow et al. (2009), Nasseh and Strauss (2000), Bekaert et al. (2011), Shamsuddin and Kim (2003), Cotter and Stevenson (2006); Pukthuanthong and Roll (2009), and Ryan and Gerard (2003).
A plethora of literature concludes that interdependence of stock market prices in different countries increases during and after financial hardships (Bekaert et al., 2011, 2008; Berger, 2011; Donadelli and Persha, 2014; Eiling and Gerard, 2007; Lahrech and Sylwester, 2011; Rajan and Zingales, 2003).Arshanapalli and Doukas (1993) analyzed the stock price comovement in major stock exchanges namely, the Dow Jones, FAZ (Frankfurt), FTSE 100, Nikkei and CAC (Paris). The study indicated that except for the Nikkei, stock prices of the under study markets have shown significant synchronization after the stock market crises of October 1987. Arshanapalli et al. (1995) also found significant increase in interdependence of Asian-Pacific markets after the 1987 collapse. Longin and Solnik (1995) and Karolyi and Stulz (1996) while investigating the interdependence of major European countries and Japanese and U.S stock markets respectively, concluded that correlation between stock prices increases during unstable and volatile market conditions, highly depressing the returns expected from portfolio diversification.

Interdependence of stock prices of international stock markets was also investigated by Hassan and Naka (1996) and Bekaert et al. (2008) for the period before and after 1987 stock markets crash. The study revealed that there was a significant multilateral relationship among the stock prices of United States, United Kingdom, Japan, and Germany for the period under investigation. In addition, the results of the study also highlighted that the United States stocks were the most influential in affecting the stocks of the remaining under investigation countries during stock market crises. Studies such as Lucey and Zhang (2010), Brooks and Del Negro (2004); Lahrech and Sylwester (2011), and Höchstötter et al. (2014) also discussed the co-movements among equity markets. Liu et al. (1999) have studied the changes in stock prices of Japan, U.S, Singapore, Hong Kong, Taiwan and Thailand. The study found that relation between stock returns of Asian-Pacific markets has gained strength after 1987 stock market crash. The study also concluded that increased relationship between stock price changes has reduced the benefit of diversification in equity market.

The influence of the Japanese and the United States markets on the stocks of Asian countries was empirically analyzed by the study of Cha and Oh (2000). The findings of the study indicated that co-movement between the stock markets of Japan and United States, and developing Asian countries has started to change after 1987 stock market crash. Financial contagion further explored by the different researchers such as Bae et al. (2003), Rua and Nunes (2009), Chue (2005), Van Rijckeghem and Weder (2003), Pretorius (2002), Johnson and Soenen (2003), Asgharian et al. (2013), Claus and Lucey (2012) and Forbes and Rigobon (2002). Another interesting finding of the study was that cor- 
relation between these markets has gained strength after the 1997 currency crises in Asia. Yang (2002) seeks to determine the long-term co-movement in the stock markets of East Asian countries namely, Hong Kong, Indonesia, Korea, Malaysia, Thailand, the Philippines, Singapore and Taiwan. The results of his study suggested that there was no synchronization among the stock prices of these countries during the 1997 to 1998 financial distress. Daly (2003) examined the static and dynamic linkages among the stock markets of Indonesia, Malaysia, Philippines, Singapore, Thailand, and that of the stock markets of developed countries like Australia, Germany and the United States from April 1990 until October 2001. The study concluded that there was a strong correlation among these stock markets. The study also suggested that except for Malaysia and Singapore the co-movement of stock prices gained more strength after 1997 financial crises.

Another group of studies have investigated the comovement of stock markets returns citing reasons like influence of some advanced stock markets on other markets, economic interdependence, trade relationship, and geographical location on the stock markets synchronization. Findings of Eun and Shim (1989) indicated that US stock markets were the most influential in affecting the stock markets of other countries. Roca, Selvanathan and Shepherd (1998) analyzed the equity prices correlation among the stock markets of Malaysia, Singapore, Thailand, Indonesia and Philippines (five countries of Association of South East Asian Nations). The findings of the study pointed out that there was no long run co-movement in the stock market of these countries. Another conclusion of the study was that Malaysia was the most influential market in these countries; also, Neaime (2012), Thalassinos et al. (2003), Caporale et al. (2005), Forbes and Rigobon (2002), Agarwal and Taffler (2008), Voronkova (2004), Johnson and Soenen (2003), Barari (2004), Phylaktis and Xia (2006), Berben and Jansen (2005) and Brooks and Negro (2006) focused on the long term relationship in equity markets. Hashmi and Xingyun (2001) sought to determine the linkages among Southeast Asian countries, Tokyo and New York stock markets before and after the Asian financial crash. The study concluded that New York stock market had a strong influence on the Southeast Asian stock markets but the effect is unilateral. The Tokyo stock market appeared to be isolated in the region. The Malaysian Stock Exchange was also found to be isolated from the regional stock markets after the Asian financial crash.

In the same footing, Walti (2005) while studying the stock returns of fifteen industrialized countries for the period 1973 to 1997, concluded that trade, financial integration and fixed exchange rates enhanced crossmarkets co-movements. Morgado and Tavares (2007) investigated the effect of trade on the co-movements of share prices of 40 developed and emerging markets for the period 19701990. The study concluded that trade linkages have significant impact on stock prices synchronization. Further studies such as Sun and Zhang (2001), Sun and Seiler (2013), Chi et al. (2009), Chien (2010), Mei and Clutter (2010), and Cascio and Clutter (2008) focused on the long run relationships in real estate markets. Forbes and Rigobon (2002) pointed out that during volatile market conditions the relation between various market prices were strongly affected by heteroskedesticity. They concluded that it was economic interdependence and not the markets volatility which force these markets to move together. Ampomah (2008) concluded that African stock markets were not synchronized with international equity markets and thus suitable for returns from portfolio diversification.

On the basis of all above discussion it can be summarized that different researchers studied the equity markets of different countries with different perspective. Some of them analyzed the cointegration among the equity markets of different countries by employing different econometric models. But there exists limited literature which focuses on analyzing the cointegration between Pakistan and its major trading partners. To do this, we use different latest methodologies available in the econometrics literature for cointegration. We apply the Johansen approach for co-integration along with error correction model, variance decomposition analysis and impulse response analysis. The discussion regarding the data and methodological issues are presented in the following section.

\section{Data and Research Methodology}

Study uses the Bloomberg database to collect the time series of the equity indices of major trading partners of Pakistan. Our study period consists of almost twelve years on weekly basis from January 2004 to October 2015. This study considers the major trading partner of Pakistan consisting of China, France, Germany, Hong Kong, Japan, Korea, Malaysia, UK and USA. Table 1 presents the details of selected stock indices of Pakistan and its major trading partner.

The change in the price of each index is calculated by using the following equation:

$$
R_{t}=\ln \left(\frac{Y_{t}}{Y_{t-1}}\right) \ldots \ldots(1)
$$

Where $R_{t}$ is the continuous compounded return for week $t$ and $Y_{t}$ and $Y_{(t-1)}$ stand for closing values for week $t$ and $t-1$ respectively.

Stationarity of the time series is one of the basic assumptions of the Cointegration analysis. This study uses the Augmented Dickey Fuller (ADF) test (Dickey and Fuller, 1979) and Phillips-Perron (PP) test (Phillips and Perron, 1988), to test the level of integration of the 
Table 1: Indices of the Pakistani equity markets and its major trading partner

\begin{tabular}{ll}
\hline Country Name & Index \\
\hline Pakistan & KSE-100 INDEX \\
China & CHINA SHANGHAI COMPOSITE INDEX \\
France & CAC 40 \\
Germany & DAX \\
Hong Kong & HANG SENG INDEX \\
Japan & NIKKEI 225 \\
Korea & KOSPI COMPOSITE INDEX \\
Malaysia & KLSE \\
UK & FTSE-100 \\
USA & S \& P 500 INDEX \\
\hline
\end{tabular}

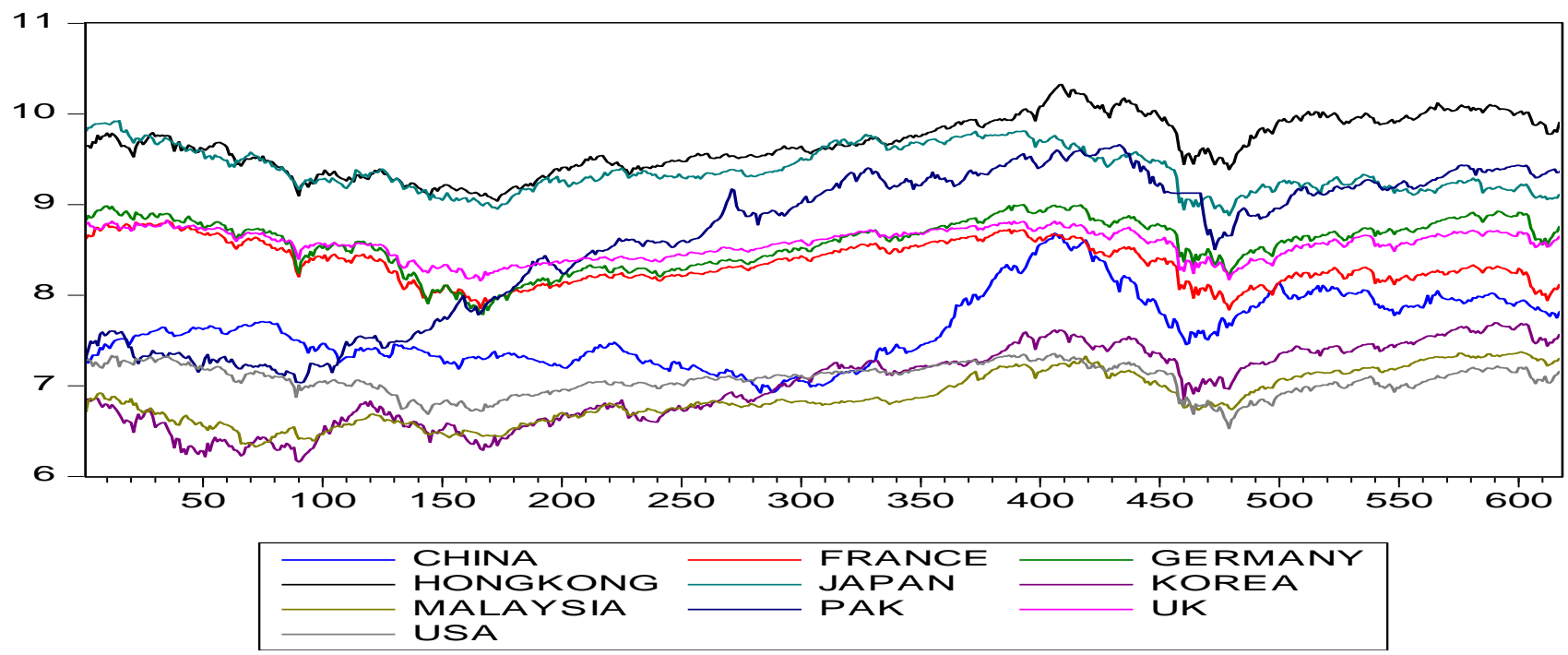

Figure 1:

all the time series. Here the null hypothesis, i.e. the series has a unit root is tested. The acceptance or rejection of this null hypothesis will determine the stationarity in the time series data. The Augmented Dickey Fuller (ADF) test finds out the possibility or existence of unit root by employing an autoregressive (AR) model. The equation for an autoregressive AR (1) model is given below:

$$
P_{t}=\varphi P_{t-1}+\varepsilon_{t}
$$

Where, $P_{t}$ is the variable under study, $t$ shows the time period and $\varepsilon_{t}$ denotes the error term for that period. The following equation can be used as regression equation:

$$
\Delta P_{t}=(\varphi-1) P_{t-1}+\mu_{t}=\delta P_{t-1}+\varepsilon_{t}
$$

Here, $\Delta$ is the symbol of first difference operator. The model of above equation can be estimated for unit root in ADF test. The assumptions behind the Augmented Dickey Fuller (ADF) test are quite strict and it believes on the assumption that the disturbance terms are independent and are homo-skedastic i.e. the variance of the disturbance term is constant over time. So this study also uses a relatively less strict test for the same purpose. The Phillips-Perron (PP) test also applies to check out the stationarity of the time series. The PP test considered a less strict test than of ADF test and it works under the assumption that the error terms are heterogeneously distributed. Mathematically, it can be 
written as:

$$
P_{t}=\rho+{ }_{1} P_{t-1}+{ }_{t}\left\{t-\frac{T}{2}\right\}+\varepsilon_{t}
$$

This study uses the maximum likelihood based Johansen (1994) approach to investigate the long-term relationship. Johansen (1994) co-integration analysis examines the existence of long term co-movement of the any time series. This approach of co-integration put forwards two types of likelihood ratio test for the presence of cointegration equations among the variables. It includes the Trace statistics and maximum eigenvalue test. The maximum eigenvalue test considers the null hypothesis i.e. there are at most $r$ co-integrating vector beside the alternative of the $\mathrm{r}+1$ co-integrating vector and statistically, it can be written as:

$$
\lambda(r)=-N \sum^{I} n\left(1-\lambda_{r+1}\right)
$$

In the above equation, $\lambda_{r+1}, \lambda_{r+2}, \ldots, \lambda_{n}$ are the (n r) smallest squared canonical correlation and $\mathrm{N}$ shows the total number of observations. On the other hand the Trace statistics examines the null hypothesis of $\mathrm{r}$ cointegrating vector beside the alternative of $r$ or greater than $\mathrm{r}$ co-integrating vector and statistically, it can be written as:

$$
\lambda(r)=-N \sum^{I} n\left(1-\lambda_{i}\right)
$$

In the co-integration analysis, after the determination of unit root the next step is to find out the appropriate lag length for vector auto-regression (VAR). The appropriate lag length will be found by considering the Akaike information criterion (AIC), Schwarz information criterion (SIC) and Hannan-Quinn information criterion (HQ). The appropriate lag length will be the lag length where the value of these criteria will be found minimum.

If there is co-integration in the equity markets then VECM can be used to find out the short-term interaction between the different time series. ? explored that if there is long run relationship then to capture the short term divergence, a term of error correction is added into the system of equations. Hence the innovation in the explained variable is a function of the level of dis-equilibrium and change in the independent variables. Here the level of dis-equilibrium is confined by the error correction term in the model. According to the Granger representation, an error correction model (with 2 co-integrating variable) has the following form:

$$
\Delta Y_{t}=\rho+\varphi X_{t}+\varphi_{1} \varepsilon_{t-1}+\vartheta_{t}
$$

Where, $\varepsilon_{t-1}$ shows the error correction term and $\varphi_{1}$ is the coefficient of short tern adjustments. To test out of sample causality, variance composition is also used in this study. It shows the decomposition of the change in the variable, in a specified period which occurs due to the changes due to its own dynamics and also shows the contribution of other variables in prior period. Lütkepohl and Poskitt (1991) presents an impulse response analysis to analyze that how quickly the shocks in one equity market are transferred to rest of the equity markets. The moving average of the vector auto-regression model is used to acquire this.

\section{Empirical Results}

To grasp a rough idea about the long term relationship between the equity market of Pakistan and its major trading partners, we present a line graph. The figure 1 plots the equity indices in their natural logarithmic form of all the studied equity markets.

\subsection{Descriptive Analysis}

Table 2 reports the results of descriptive statistics. The average weekly return in percentage terms of the KSE-100 index is 0.34 percent having a standard deviation of 3.7 percent. Equity markets of USA, UK, Japan, Germany and France are offering weekly negative returns to their investors while the equity markets of Malaysia, Korea, Hong Kong and China are offering positive weekly returns. The result of Skewness which is a measure of normality of data shows that the return of all the indices is negatively skewed or skewed towards left. Similarly the value of kurtosis also supports the results of skewness. One can also find the maximum and minimum value of the weekly returns of all the equity markets for the entire study period.

\subsubsection{Correlation Matrix}

Results of correlation analysis are presented in table 3. Correlation matrix can be used to comment upon the direction and strength of relationship between two variables. From table 3, it can be safely concluded that Pakistan has a weak relationship among all its major trading partners equity market. The relatively strong correlation of KSE-100 index is observed with the equity market of Korea having correlation coefficient $(\mathrm{r})$ of 0.18. Interestingly, equity market of Pakistan has positive association with its entire major trading partners although the strength of this association changes from market to market. Generally it is agreed that correlation matrix is a weak measure to check the relationship between variables as it only discusses the strength and direction of relation without discussing any cause and effect of relationship. Hence we also applied powerful test to further analyze the relationship. 
Table 2: Descriptive Analysis

\begin{tabular}{lcccccccccc}
\hline & PAK & USA & UK & Malaysia & Korea & Japan & Hong Kong & Germany & France & China \\
\hline Mean & 0.0034 & -0.0002 & -0.0003 & 0.001 & 0.0012 & -0.001 & 0.0004 & -0.0002 & -0.0009 & 0.0008 \\
Median & 0.0076 & 0.0009 & 0.0019 & 0.0021 & 0.0058 & 0.0016 & 0.0021 & 0.0033 & 0.0014 & 0 \\
Std. Dev. & 0.037 & 0.028 & 0.0269 & 0.0225 & 0.0389 & 0.0321 & 0.0339 & 0.0355 & 0.0326 & 0.0356 \\
Kurtosis & 3.6236 & 6.5485 & 11.6897 & 3.8591 & 3.5755 & 9.4137 & 2.2101 & 5.0041 & 6.5638 & 1.7684 \\
Skewness & -0.982 & -0.619 & -1.1454 & -0.4024 & -0.54 & -1.29 & -0.2142 & -0.6708 & -0.969 & 0.1509 \\
Range & 0.3288 & 0.3368 & 0.3621 & 0.2404 & 0.3996 & 0.3933 & 0.2953 & 0.3929 & 0.3748 & 0.2884 \\
Minimum & -0.2 & -0.2 & -0.2363 & -0.1145 & -0.229 & -0.278 & -0.1782 & -0.2435 & -0.25 & -0.149 \\
Maximum & 0.128 & 0.1359 & 0.1258 & 0.1259 & 0.1703 & 0.1145 & 0.1172 & 0.1494 & 0.1243 & 0.1394 \\
\hline
\end{tabular}

Table 3: Correlation Matrix

\begin{tabular}{|c|c|c|c|c|c|c|c|c|c|c|}
\hline & PAK & USA & UK & Malaysia & Korea & Japan & HongKong & Germany & France & China \\
\hline PAK & 1 & & & & & & & & & \\
\hline USA & 0.131 & 1 & & & & & & & & \\
\hline UK & 0.109 & 0.7621 & 1 & & & & & & & \\
\hline Malaysia & 0.145 & 0.2684 & 0.2903 & 1 & & & & & & \\
\hline Korea & 0.179 & 0.5095 & 0.491 & 0.3647 & 1 & & & & & \\
\hline Japan & 0.116 & 0.5238 & 0.5808 & 0.3722 & 0.6089 & 1 & & & & \\
\hline Hong Kong & 0.127 & 0.5199 & 0.6292 & 0.4574 & 0.6409 & 0.6259 & 1 & & & \\
\hline Germany & 0.146 & 0.76 & 0.8535 & 0.3488 & 0.5551 & 0.5889 & 0.6099 & 1 & & \\
\hline France & 0.142 & 0.7707 & 0.9016 & 0.3111 & 0.5224 & 0.5927 & 0.6046 & 0.9149 & 1 & \\
\hline China & 0.041 & 0.0869 & 0.0958 & 0.2128 & 0.1739 & 0.176 & 0.2598 & 0.1079 & 0.0946 & 1 \\
\hline
\end{tabular}

\subsubsection{Unit Root test}

Stationarity is one of the key concepts in the time series data. It is necessary to check the data for Stationarity to avoid the problem of spurious regression Asaolu and Ogunmuyiwa (2011). This particular study uses the unit root test to check the Stationarity of time series. We apply Augmented Dickey and Fuller (1979) and Phillips and Perron (1988). The results of both of the ADF and PP test are presented in table 4. In unit root test the null hypothesis which is a particular time series hypothesis having a unit root is tested against the alternate hypothesis claiming that particular time series is stationary. From the table, on the basis of ADF test it can be easily concluded that all the equity indices are not Stationarity at first level but all become stationary after their first difference or all the time series data is integrated of order one i.e. I(1). Results of PP also support the results of ADF test. Hence one can confirm the application of Johansen approach as all the time series are integrated at the same level i.e. I(1).

Before the application of JJ approach, the determination of appropriate lag length is considered an important step. To determine the appropriate lag length of this study we apply different tests up to eight lags. The results of AIC, SC and HQ are presented in table 5. According to the Schwarz information criterion the appropriate lag length for this system is one (1). So for onward, we use lag length for VAR model which is equal to one.

This study uses VAR base Johansen (1991, 1995) procedure for the co-integration which is maximum likelihood based procedure. We have applied two types of test which is suggested by Johansen: (1) Trace Test and (2) Max. eigen value test. The results of both of the cointegration test are presented in table 6 and 7 respectively. The result of Trace test in multivariate 
Table 4: Results of Unit Root test

\begin{tabular}{|c|c|c|c|c|}
\hline & ADF (Level) & ADF (First Dif.) & PP (level) & PP (First Dif.) \\
\hline Pakistan & -0.98 & -22.84 & -1.1 & -23.07 \\
\hline USA & -2.31 & -27.4 & -2.22 & -27.4 \\
\hline UK & -2.29 & -26.56 & -2.17 & -26.63 \\
\hline Malaysia & -0.33 & -15.97 & -0.53 & -24.21 \\
\hline Korea & -0.62 & -25.45 & -0.6 & -25.45 \\
\hline Japan & -1.94 & -25.86 & -1.96 & -25.84 \\
\hline Hong Kong & -1.41 & -24.98 & -1.55 & -25.04 \\
\hline Germany & -1.72 & -25.48 & -1.73 & -25.47 \\
\hline France & -1.57 & -26.49 & -1.51 & -26.51 \\
\hline China & -1.3 & -23.54 & -1.62 & -24.07 \\
\hline \multicolumn{5}{|c|}{ Critical Values } \\
\hline $1 \%$ & -3.44 & -3.44 & -3.44 & -3.44 \\
\hline $5 \%$ & -2.87 & -2.87 & -2.87 & -2.87 \\
\hline $10 \%$ & -2.57 & -2.57 & -2.57 & -2.57 \\
\hline
\end{tabular}

framework suggests that there exist two cointegrating equations at $5 \%$ level. On the other hand, Max. Eigen value test authenticates the one cointegrating equation at $5 \%$ level.

To further analyze the long term nature of relationship between equity market of Pakistan and its major trading partner, we also apply the Johansen approach in bivariate framework. For this purpose we run the Johansen approach between Pakistani equity markets and equity market of each of its trading partners. The results of both tests, i.e. Trace test and Max. Eigen value test are presented in table8. On the basis of Bivariate cointegration analysis it is clear that the equity market of Pakistan has no long term relationship with

Table 5: VAR Lag Order Selection Criteria

\begin{tabular}{lccc}
\hline Lag & AIC & SC & HQ \\
\hline 0 & 147.56 & 147.64 & 147.59 \\
1 & 116.91 & 117.7 & 117.21 \\
2 & 116.74 & 118.26 & 117.33 \\
3 & 116.81 & 119.05 & 117.68 \\
4 & 116.91 & 119.88 & 118.07 \\
5 & 116.96 & 120.65 & 118.39 \\
6 & 117.06 & 121.47 & 118.77 \\
7 & 117.11 & 122.25 & 119.11 \\
8 & 117.17 & 123.03 & 119.45 \\
\hline
\end{tabular}


Table 6: VAR Lag Order Selection Criteria

\begin{tabular}{|c|c|c|c|c|}
\hline Hypothesis & Eigen value & Trace Statistic & Critical Value 5\% & Prob.* \\
\hline \multicolumn{5}{|c|}{ Lag Length $=1$} \\
\hline $\mathrm{r}=0$ & 0.1075 & 276.04 & 239.24 & 0.0003 \\
\hline$r_{i} 1$ & 0.082 & 205.95 & 197.37 & 0.0175 \\
\hline$r_{i} 2$ & 0.071 & 153.26 & 159.53 & 0.1041 \\
\hline$r_{i} 3$ & 0.0603 & 107.92 & 125.62 & 0.3564 \\
\hline $\mathrm{r} ; 4$ & 0.0439 & 69.585 & 95.75 & 0.7362 \\
\hline $\mathrm{r} ; 5$ & 0.0261 & 41.916 & 69.82 & 0.913 \\
\hline$r ; 6$ & 0.0179 & 25.602 & 47.86 & 0.9016 \\
\hline$r_{i} 7$ & 0.0151 & 14.496 & 29.8 & 0.8117 \\
\hline$r ; 8$ & 0.0082 & 5.097 & 15.49 & 0.7984 \\
\hline r 9 & 0 & 0.001 & 3.84 & 0.9782 \\
\hline
\end{tabular}

*MacKinnon-Haug-Michelis (1999) p-values

Table 7: Multivariate Co-integration test (Max-Eigen Value Statistics)

\begin{tabular}{lcccc}
\hline Hypothesis & Eigen value & Trace Statistic & Critical Value 5\% & Prob.* $^{*}$ \\
\hline Lag Length $=1$ & & & & \\
r $=0$ & 0.108 & 70.086 & 64.505 & 0.013 \\
r $_{i}$ & 0.082 & 52.689 & 58.434 & 0.165 \\
r $_{i}$ & 0.071 & 45.346 & 52.363 & 0.218 \\
r $_{i}$ & 0.06 & 38.332 & 46.231 & 0.272 \\
r $_{i}$ & 0.044 & 27.669 & 40.078 & 0.586 \\
r $_{5}$ & 0.026 & 16.314 & 33.877 & 0.945 \\
r $_{i}$ & 0.018 & 11.106 & 27.584 & 0.963 \\
r $_{i}$ & 0.015 & 9.399 & 21.132 & 0.799 \\
r $_{i}$ & 0.008 & 5.096 & 14.265 & 0.73 \\
r $_{i} 9$ & 0 & 0.001 & 3.841 & 0.978 \\
\hline
\end{tabular}

${ }^{*}$ MacKinnon-Haug-Michelis (1999) p-values

any of the equity markets of its major trading partners i.e. China, France, Germany, Hong Kong, Japan, Korea, Malaysia, UK and USA. Both of the tests for cointegration confirm the results of each other as presented at table 8. Hence Pakistani investor can get the benefit of portfolio diversification in the equity markets of its major trading partners in the long run.

\subsubsection{Pair-wise Granger Causality Tests}

Granger (1969) idea can be used to find out the lead and lag nature of relationship between two variables. There may be unidirectional or bidirectional causality in variables. The results of pair wise Granger Causality test are presented in table 9. From the table it is evident that there exists no causality (unidirectional or bidirectional) between the equity markets of Pakistan and China, France, Korea, Malaysia and USA. But ac- 
Table 8: Bivariate Co-integration test

\begin{tabular}{|c|c|c|c|}
\hline & Country Name & Test type & Result \\
\hline \multirow[t]{2}{*}{ Pakistan } & China & Trace Test & No Cointegration \\
\hline & & Max-Eigen Value Test & \\
\hline \multirow[t]{2}{*}{ Pakistan } & France & Trace Test & No Cointegration \\
\hline & & Max-Eigen Value Test & \\
\hline \multirow[t]{2}{*}{ Pakistan } & Germany & Trace Test & No Cointegration \\
\hline & & Max-Eigen Value Test & \\
\hline \multirow[t]{2}{*}{ Pakistan } & Hong Kong & Trace Test & No Cointegration \\
\hline & & Max-Eigen Value Test & \\
\hline \multirow[t]{2}{*}{ Pakistan } & Japan & Trace Test & No Cointegration \\
\hline & & Max-Eigen Value Test & \\
\hline \multirow[t]{2}{*}{ Pakistan } & Korea & Trace Test & No Cointegration \\
\hline & & Max-Eigen Value Test & \\
\hline \multirow[t]{2}{*}{ Pakistan } & Malaysia & Trace Test & No Cointegration \\
\hline & & Max-Eigen Value Test & \\
\hline \multirow[t]{2}{*}{ Pakistan } & UK & Trace Test & No Cointegration \\
\hline & & Max-Eigen Value Test & \\
\hline \multirow[t]{2}{*}{ Pakistan } & USA & Trace Test & No Cointegration \\
\hline & & Max-Eigen Value Test & \\
\hline
\end{tabular}

cording to table 9, there exists a unidirectional causality between the equity market of Pakistan and Germany, Hong Kong, Japan and UK.

\subsubsection{Error Correction model}

To further analyze the nature of relationship between equity markets of Pakistan and its major trading partners, we also used the vector error correction model. The results of VECM are presented at table 10 . Basically it uncovers the speed of adjustment from the disequilibrium to equilibrium in the short term. From the table, the coefficient of ECM model is -0.8821 . The negative sign of this coefficient shows the direction of movement from disequilibrium to equilibrium. It can be safely said that among the total disequilibrium in the past period, $82 \%$ of this is adjusted in current period. The mathematical equation of VECM is also given below.

\subsubsection{Variance Decomposition Analysis}

Variance decomposition along with the impulse response analysis uncovers the wealth of information regarding the dynamic effect and this focus on the short term nature of interaction among the equity markets of Pakistan and its major trading partners. Variance decomposition analysis uncovers the fact that whether and up to what extent other equity markets are explaining the total variation in the equity markets of Pakistan. Hence it gives the relative importance of other countries equity markets towards explaining the shocks in Pakistani equity markets. The results of variance decomposition test are presented in table 10. On the basis of this it can be said that most of the shocks or variation in the Pakistani equity markets are due to its own dynamics. Anyhow the equity markets of France, Korea and Germany are exerting pressure on the Pakistani equity markets. Impulse response function diagramcally analyze the response of the equity markets of Pakistan towards one period standard deviation variations to the innovation of system. It further shows the direction of response to each of the shocks. The results of impulse response analysis are presented in appendix(Figure2). 
Table 9: Pair-wise Granger Causality Tests

\begin{tabular}{lccc}
\hline R_PAK does not Granger Cause R_FRANCE & 1.0669 & 0.3021 & No \\
R_FRANCE does not Granger Cause R_PAK & 3.5336 & 0.0606 & Causality \\
\hline R_PAK does not Granger Cause R_GERMANY & 0.154 & 0.6949 & Unidirectional \\
R_GERMANY does not Granger Cause R_PAK & 6.267 & 0.0126 & Causality \\
\hline R_PAK does not Granger Cause R_HONG KONG & 1.8431 & 0.1751 & Unidirectional \\
R-HONG KONG does not Granger Cause R_PAK & 5.944 & 0.0151 & Causality \\
\hline R_PAK does not Granger Cause R_JAPAN & 0.8606 & 0.3539 & Unidirectional \\
R_JAPAN does not Granger Cause R_PAK & 4.2326 & 0.0401 & Causality \\
\hline R_PAK does not Granger Cause R_KOREA & 2.1224 & 0.1457 & No \\
R_KOREA does not Granger Cause R_PAK & 0.8303 & 0.3625 & Causality \\
\hline R_PAK does not Granger Cause R_MALAYSIA & 1.448 & 0.2293 & No \\
R_MALAYSIA does not Granger Cause R_PAK & 0.0284 & 0.8662 & Causality \\
\hline R_USA does not Granger Cause R_PAK & 2.6234 & 0.1058 & No \\
R_PAK does not Granger Cause R_USA & 0.0034 & 0.9537 & Causality \\
\hline R_UK does not Granger Cause R_PAK & 5.841 & 0.0159 & Unidirectional \\
R_PAK does not Granger Cause R_UK & 0.6662 & 0.4147 & Causality \\
\hline
\end{tabular}

\section{Conclusions}

The objective of this study was to empirically investigate co-movement in the stock markets of the countries with which Pakistan has major trade relations. Hence it is an attempt to analyze the long term as well as short term relationship between Pakistani equity market and equity markets of its major trading partners. The total study period consists of almost twelve years on weekly basis from January 2003 to October 2014. This research uses KSE-100 index as proxy for the stock index in Pakistan. This study considers the major trading partner of Pakistan consisting of China, France, Germany, Hong Kong, Japan, Korea, Malaysia, UK and USA. Descriptive statistics showed that equity markets of USA, UK, Japan, Germany and France are offering weekly negative returns to their investors while the equity markets of Malaysia, Korea, Hong Kong and China are offering positive weekly returns. On the basis of correlation matrix, it is evident that equity market of Pakistan has positive association with its entire major trading partners although the strength of this association changes from market to market. Generally it is agreed that correlation matrix is a weak measure to check the relationship between variables as it only discusses the strength and direction of relation without discussing any cause and effect of relationship.

Unit root test has been conducted to check the Stationarity of time series. From the Augmented Dickey and Fuller (1979) and Phillips and Perron (1988) test it can be easily concluded that all the equity indices are not Stationarity at first level but all become stationary after their first difference or all the time series data is integrated of order one. On the basis of Bivariate cointegration analysis (VAR base Johansen $(1991,1995)$ it was cleared that the equity market of Pakistan has no long term relationship with any of the equity markets of its major trading partners i.e. China, France, Germany, Hong Kong, Japan, Korea, Malaysia, UK and USA. The results of pair wise Granger Causality test suggested that there exists no causality (unidirectional or bidirectional) between the equity markets of Pakistan and China, France, Korea, Malaysia and USA. On the other hand, there exists unidirectional causality between the equity market of Pakistan and Germany, Hong Kong, Japan and UK. Variance decomposition along with the impulse response analysis reveals that most of the shocks or variation in the Pakistani equity markets was due to its own dynamics. Anyhow the equity markets of France, Korea and Germany were exerting pressure on the Pakistani equity markets.

On the basis of battery of econometrics, it was con- 
Table 10: Error Correction Model

\begin{tabular}{|c|c|c|c|c|}
\hline Regressor & Coefficient & SE & T-Ratio & Prob. \\
\hline USA & 0.0631 & 0.0872 & 0.7228 & 0.47 \\
\hline UK & -0.1618 & 0.1354 & -1.195 & 0.233 \\
\hline Malaysia & 0.1167 & 0.0775 & 1.5057 & 0.133 \\
\hline Korea & 0.1336 & 0.0541 & 2.4691 & 0.014 \\
\hline Japan & -0.0426 & 0.0656 & -0.649 & 0.517 \\
\hline Hong Kong & -0.0159 & 0.0692 & -0.2305 & 0.818 \\
\hline Germany & 0.0419 & 0.108 & 0.3884 & 0.698 \\
\hline France & 0.1137 & 0.1371 & 0.8298 & 0.407 \\
\hline China & 0.004 & 0.0434 & 0.0915 & 0.927 \\
\hline ecm $(-1)$ & -0.8821 & 0.0396 & -22.2873 & 0 \\
\hline R-Squared & 0.4617 & R-Bar-Squared & & 0.4537 \\
\hline S.E. of Regression & 0.0362 & Equation Log-likelihood & & 1173.8 \\
\hline SB Criterion & 1141.7 & Akaike Info. Criterion & & 1163.8 \\
\hline F-stat. & 57.7594[.000] & DW-statistic & & 2.0306 \\
\hline
\end{tabular}

Table 11: Variance Decomposition Analysis

\begin{tabular}{lcccccccccc}
\hline Period & Pak & China & France & Germany & Hong Kong & Japan & Korea & Malaysia & UK & USA \\
\hline 1 & 96.37 & 0.06 & 2 & 0.24 & 0.15 & 0.02 & 0.91 & 0.25 & 0 & 0 \\
2 & 94.27 & 0.07 & 2.69 & 0.85 & 0.47 & 0.06 & 1.07 & 0.41 & 0.11 & 0.01 \\
3 & 94.14 & 0.07 & 2.71 & 0.85 & 0.47 & 0.06 & 1.06 & 0.41 & 0.11 & 0.12 \\
4 & 94.12 & 0.07 & 2.71 & 0.85 & 0.47 & 0.06 & 1.07 & 0.41 & 0.11 & 0.13 \\
5 & 94.12 & 0.07 & 2.71 & 0.85 & 0.47 & 0.06 & 1.07 & 0.41 & 0.11 & 0.13 \\
6 & 94.12 & 0.07 & 2.71 & 0.85 & 0.47 & 0.06 & 1.07 & 0.41 & 0.11 & 0.13 \\
7 & 94.12 & 0.07 & 2.71 & 0.85 & 0.47 & 0.06 & 1.07 & 0.41 & 0.11 & 0.13 \\
8 & 94.12 & 0.07 & 2.71 & 0.85 & 0.47 & 0.06 & 1.07 & 0.41 & 0.11 & 0.13 \\
9 & 94.12 & 0.07 & 2.71 & 0.85 & 0.47 & 0.06 & 1.07 & 0.41 & 0.11 & 0.13 \\
10 & 94.12 & 0.07 & 2.71 & 0.85 & 0.47 & 0.06 & 1.07 & 0.41 & 0.11 & 0.13 \\
\hline
\end{tabular}

cluded that Pakistani equity market has no long term relationship with its major trading countries equity markets. This study is important and lucrative for in- ternational investors as it may help guide their investments decisions. Since all these Pakistani trading partners countries equity markets have no empirical long 
Response to Cholesky One S.D. Innovations \pm 2 S.E.

Response of RPAK to RCHNA

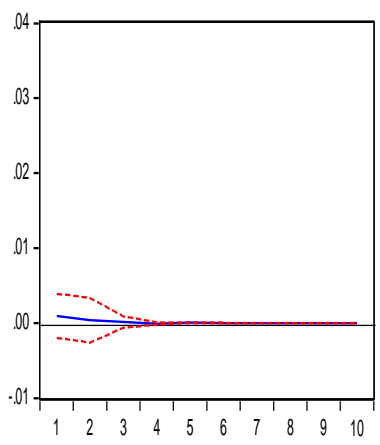

Response of RPAK to RJAPAN

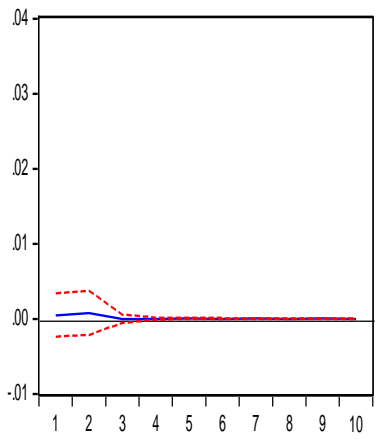

Response of RPAK to RUK

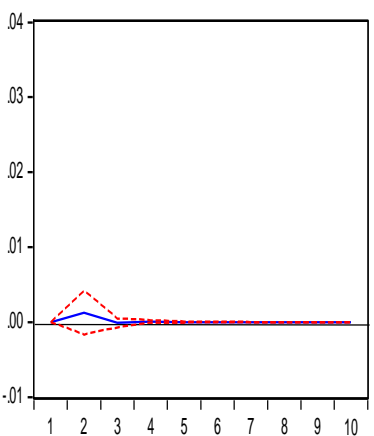

Response of RPAK to RFPANCE

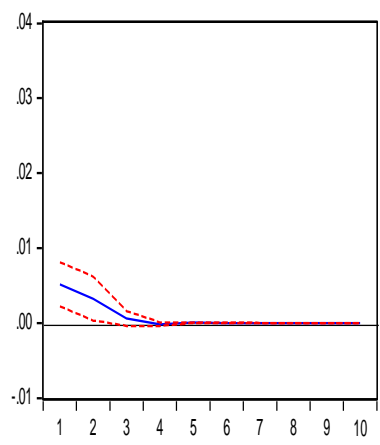

Response of RPAK to RKOREA

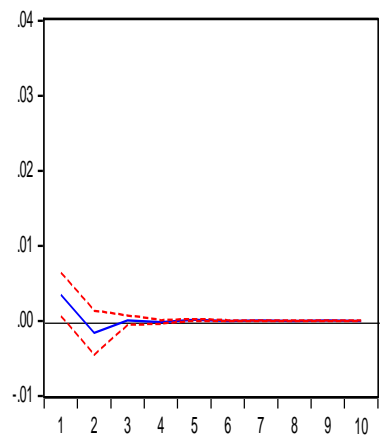

Response of RPAK to RUSA

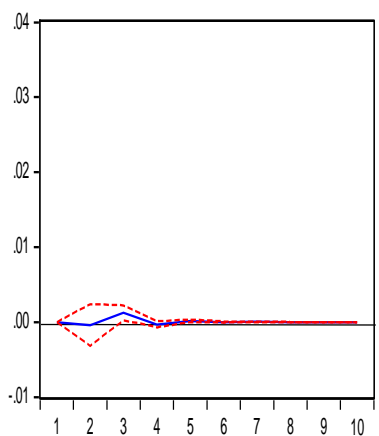

Response of RPAK to RGERMANY

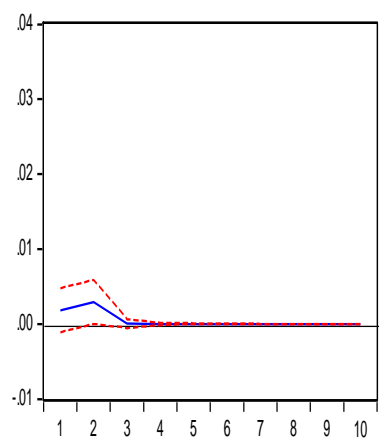

Response of RPAK to RMALAYSIA

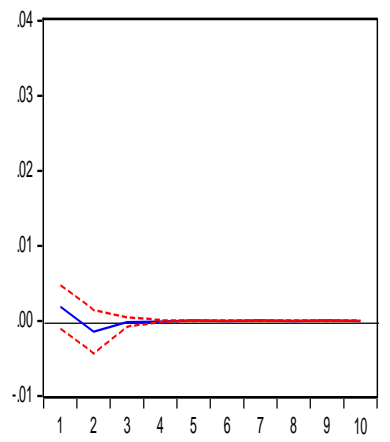

Response of RPAK to RHONGKONG

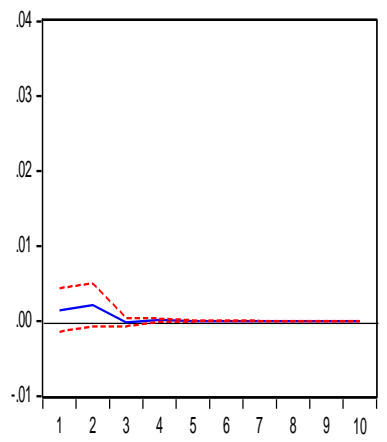

Response of RPAK to RPAK

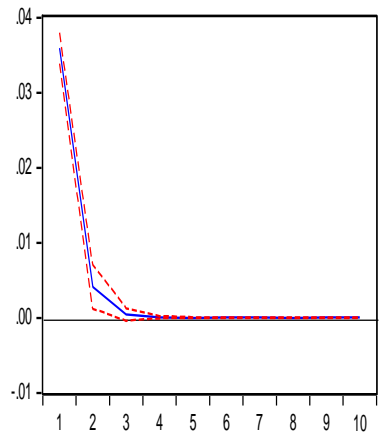

Figure 2: Appendix: Impulse Response Analysis

term relation with Pakistani equity markets so they can get the benefit of portfolio diversification by investing in the equity markets of Pakistan. This study is also helpful for Pakistani investor, fund managers, policy makers and regulators as it guides their investment decisions. They should be vigilant regarding the comovement between equity markets before taking any prosperous decision. Hence Pakistani investors can get the benefit of portfolio diversification in the equity markets of its major trading partners in the long run.

\section{References}

Agarwal, V. and Taffler, R. (2008). Comparing the performance of market-based and accounting-based bankruptcy prediction models. Journal of Banking E Finance, 32(8):15411551.

Ampomah, S. (2008). An empirical examination of the interlinkages between african stock markets. University of Surrey, Guildford, United Kingdom. Electronic copy available at http://ssrn. com/abstract, 1311325.

Arshanapalli, B. and Doukas, J. (1993). International stock 
market linkages: Evidence from the pre-and post-october 1987 period. Journal of Banking E Finance, 17(1):193-208.

Arshanapalli, B., Doukas, J., and Lang, L. H. (1995). Pre and post-october 1987 stock market linkages between us and asian markets. Pacific-Basin Finance Journal, 3(1):57-73.

Asaolu, T. and Ogunmuyiwa, M. (2011). An econometric analysis of the impact of macroecomomic variables on stock market movement in nigeria. Asian Journal of Business Management, 3(1):72-78.

Asgharian, H., Hess, W., and Liu, L. (2013). A spatial analysis of international stock market linkages. Journal of Banking $\mathcal{E}$ Finance, 37(12):4738-4754.

Bae, K.-H., Karolyi, G. A., and Stulz, R. M. (2003). A new approach to measuring financial contagion. The Review of Financial Studies, 16(3):717-763.

Barari, M. (2004). Equity market integration in latin america: A time-varying integration score analysis. International Review of Financial Analysis, 13(5):649-668.

Bekaert, G., Harvey, C. R., Lundblad, C. T., and Siegel, S. (2011). What segments equity markets? The Review of Financial Studies, 24(12):3841-3890.

Bekaert, G., Hodrick, R. J., and Zhang, X. (2008). Is there a trend in idiosyncratic volatility. Available at SSRN 1108170.

Berben, R.-P. and Jansen, W. J. (2005). Comovement in international equity markets: A sectoral view. Journal of International Money and Finance, 24(5):832-857.

Berger, P. G. (2011). Challenges and opportunities in disclosure researcha discussion of the financial reporting environment: Review of the recent literature. Journal of Accounting and Economics, 51(1):204-218.

Brooks, R. and Del Negro, M. (2004). The rise in comovement across national stock markets: market integration or it bubble? Journal of Empirical Finance, 11(5):659-680.

Brooks, R. and Negro, M. D. (2006). Firm-level evidence on international stock market comovement. Review of Finance, 10(1):69-98.

Caporale, G. M., Cipollini, A., and Spagnolo, N. (2005). Testing for contagion: a conditional correlation analysis. Journal of Empirical Finance, 12(3):476-489.

Cascio, A. J. and Clutter, M. L. (2008). Risk and required return assessments of equity timberland investments in the united states. Forest Products Journal, 58(10):61.

Cha, B. and Oh, S. (2000). The relationship between developed equity markets and the pacific basin's emerging equity markets. International Review of Economics $\mathcal{E}$ Finance, 9(4):299-322.

Chi, W., Huang, H., Liao, Y., and Xie, H. (2009). Mandatory audit partner rotation, audit quality, and market perception: Evidence from taiwan. Contemporary Accounting Research, 26(2):359-391.
Chien, M.-S. (2010). Structural breaks and the convergence of regional house prices. The Journal of Real Estate Finance and Economics, 40(1):77-88.

Chue, T. K. (2005). Conditional market comovements, welfare, and contagions: The role of time-varying risk aversion. The Journal of Business, 78(3):949-968.

Chuluun, T. and Graham, C. (2016). Local happiness and firm behavior: Do firms in happy places invest more? Journal of Economic Behavior \& Organization, 125:41-56.

Claus, E. and Lucey, B. M. (2012). Equity market integration in the asia pacific region: Evidence from discount factors. Research in International Business and Finance, 26(2):137-163.

Cohen, L., Frazzini, A., and Malloy, C. (2008). The small world of investing: Board connections and mutual fund returns. Journal of Political Economy, 116(5):951-979.

Cotter, J. and Stevenson, S. (2006). Multivariate modeling of daily reit volatility. The Journal of Real Estate Finance and Economics, 32(3):305-325.

Daly, K. J. (2003). Southeast asian stock market linkages: evidence from pre-and post-october 1997. ASEAN Economic Bulletin, pages 73-85.

Dickey, D. A. and Fuller, W. A. (1979). Distribution of the estimators for autoregressive time series with a unit root. Journal of the American statistical association, 74(366a):427431.

Donadelli, M. and Persha, L. (2014). Understanding emerging market equity risk premia: Industries, governance and macroeconomic policy uncertainty. Research in International Business and Finance, 30:284-309.

Eiling, E. and Gerard, B. (2007). Dispersion, equity returns correlations and market integration. Unpublished working paper). University of Toronto, Toronto, Ontario, Canada.

Eun, C. S. and Shim, S. (1989). International transmission of stock market movements. Journal of financial and quantitative Analysis, 24(2):241-256.

Forbes, K. J. and Rigobon, R. (2002). No contagion, only interdependence: measuring stock market comovements. The journal of Finance, 57(5):2223-2261.

Fu, R. and Gupta-Mukherjee, S. (2014). Geography, informal information flows and mutual fund portfolios. Financial Management, 43(1):181-214.

Ghosh, M. and John, G. (1999). Governance value analysis and marketing strategy. The Journal of Marketing, pages 131-145.

Granger, C. W. (1969). Investigating causal relations by econometric models and cross-spectral methods. Econometrica: Journal of the Econometric Society, pages 424-438.

Gupta, R. and Guidi, F. (2012). Cointegration relationship and time varying co-movements among indian and asian developed stock markets. International Review of Financial Analysis, 21:10-22. 
Hashmi, A. R. and Xingyun, L. (2001). Interlinkages among south east asian stock markets (a comparison between preand post-1997-crisis periods) 1 .

Hassan, M. K. and Naka, A. (1996). Short-run and long-run dynamic linkages among international stock markets. International Review of Economics \& Finance, 5(4):387-405.

Höchstötter, M., Meyer, S., Riordan, R., and Storkenmaier, A. (2014). International stock market comovement and news. Journal of Financial Research, 37(4):519-542.

Hoque, H. A., Kim, J. H., and Pyun, C. S. (2007). A comparison of variance ratio tests of random walk: A case of asian emerging stock markets. International Review of Economics $\mathcal{E}$ Finance, 16(4):488-502.

Johansen, S. (1991). Estimation and hypothesis testing of cointegration vectors in gaussian vector autoregressive models. Econometrica: Journal of the Econometric Society, pages 1551-1580.

Johansen, S. (1994). Likelihood-based inference in cointegrated vector autoregressive models. Oxford University Press on Demand.

Johansen, S. (1995). Likelihood-based inference in cointegrated vector autoregressive models. Oxford University Press on Demand.

Johnson, R. and Soenen, L. (2003). Economic integration and stock market comovement in the americas. Journal of Multinational Financial Management, 13(1):85-100.

Kallberg, J. G., Liu, C. H., and Pasquariello, P. (2002). Regime shifts in asian equity and real estate markets. Real Estate Economics, 30(2):263-291.

Karolyi, G. A. and Stulz, R. M. (1996). Why do markets move together? an investigation of us-japan stock return comovements. The Journal of Finance, 51(3):951-986.

Kasa, K. (1992). Common stochastic trends in international stock markets. Journal of monetary Economics, 29(1):95-124.

Lahrech, A. and Sylwester, K. (2011). Us and latin american stock market linkages. Journal of International Money and Finance, 30(7):1341-1357.

Lessard, D. R. (1973). International portfolio diversification: a multivariate analysis for a group of latin american countries. The Journal of Finance, 28(3):619-633.

Levy, H. and Sarnat, M. (1970). International diversification of investment portfolios. The American Economic Review, 60(4):668-675.

Liow, K. H., Ho, K. H. D., Ibrahim, M. F., and Chen, Z. (2009). Correlation and volatility dynamics in international real estate securities markets. The Journal of Real Estate Finance and Economics, 39(2):202-223.

Liow, K. H. and Yang, H. (2005). Long-term co-memories and short-run adjustment: securitized real estate and stock markets. The Journal of Real Estate Finance and Economics, 31(3):283-300.
Liu, Y., Gopikrishnan, P., Stanley, H. E., et al. (1999). Statistical properties of the volatility of price fluctuations. Physical review e, 60(2):1390.

Longin, F. and Solnik, B. (1995). Is the correlation in international equity returns constant: 1960-1990? Journal of international money and finance, 14(1):3-26.

Lucey, B. M. and Zhang, Q. (2010). Does cultural distance matter in international stock market comovement? evidence from emerging economies around the world. Emerging Markets Review, 11(1):62-78.

Lütkepohl, H. and Poskitt, D. S. (1991). Estimating orthogonal impulse responses via vector autoregressive models. Econometric Theory, 7(4):487-496.

Markowitz, H. (1952). Portfolio selection. The journal of finance, 7(1):77-91.

Markowitz, H. (1959). Portfolio Selection, Efficent Diversification of Investments. J. Wiley.

Mei, B. and Clutter, M. L. (2010). Evaluating the financial performance of timberland investments in the united states. Forest Science, 56(5):421-428.

Morgado, P. and Tavares, J. (2007). Economic integration and the co-movement of stock returns.

Mukherjee, P. and Bose, S. (2008). Does the stock market in india move with asia?: A multivariate cointegration-vector autoregression approach. Emerging Markets Finance and Trade, 44(5):5-22.

Nasseh, A. and Strauss, J. (2000). Stock prices and domestic and international macroeconomic activity: a cointegration approach. The Quarterly Review of Economics and Finance, 40(2):229-245.

Neaime, S. (2012). The global financial crisis, financial linkages and correlations in returns and volatilities in emerging mena stock markets. Emerging Markets Review, 13(3):268-282.

Phillips, P. C. and Perron, P. (1988). Testing for a unit root in time series regression. Biometrika, 75(2):335-346.

Phylaktis, K. and Xia, L. (2006). Sources of firms' industry and country effects in emerging markets. Journal of International Money and Finance, 25(3):459-475.

Pretorius, E. (2002). Economic determinants of emerging stock market interdependence. Emerging Markets Review, 3(1):84-105.

Pukthuanthong, K. and Roll, R. (2009). Global market integration: An alternative measure and its application. Journal of Financial Economics, 94(2):214-232.

Rajan, R. G. and Zingales, L. (2003). The great reversals: the politics of financial development in the twentieth century. Journal of financial economics, 69(1):5-50. 
Rua, A. and Nunes, L. C. (2009). International comovement of stock market returns: A wavelet analysis. Journal of Empirical Finance, 16(4):632-639.

Ryan, M. and Gerard, K. (2003). future research reflections. Applied health economics and health policy, 2:55-64.

Shamsuddin, A. F. and Kim, J. H. (2003). Integration and interdependence of stock and foreign exchange markets: an australian perspective. Journal of International Financial Markets, Institutions and Money, 13(3):237-254.

Siklos, P. L. and Ng, P. (2001). Integration among asiapacific and international stock markets: Common stochastic trends and regime shifts. Pacific Economic Review, 6(1):89-110.

Solnik, B. H. (1974). An equilibrium model of the international capital market. Journal of economic theory, 8(4):500524.

Sun, C. and Zhang, D. (2001). Assessing the financial performance of forestry-related investment vehicles: Capital asset pricing model vs. arbitrage pricing theory. American Journal of Agricultural Economics, 83(3):617-628.
Sun, H. and Seiler, M. (2013). Hyperbolic discounting, reference dependence, and its implications for the housing market. Journal of Real Estate Research, 35(1):1-23.

Thalassinos, E., Kiriazidis, T., et al. (2003). Degrees of integration in international portfolio diversification: Effective systemic risk. European Research Studies Journal, 6(1-2):119130.

Van Rijckeghem, C. and Weder, B. (2003). Spillovers through banking centers: a panel data analysis of bank flows. Journal of International Money and Finance, 22(4):483-509.

Voronkova, S. (2004). Equity market integration in central european emerging markets: A cointegration analysis with shifting regimes. International Review of Financial Analysis, 13(5):633-647.

Walti, S. (2005). The macroeconomic determinants of stock market synchronization. Journal of International Banking Law, 11(10):436-441.

Wong, W.-K., Penm, J., Terrell, R. D., and Ching, K. Y. (2004). The relationship between stock markets of major developed countries and asian emerging markets. Journal of Applied Mathematics E Decision Sciences, 8(4):201-218. 